\title{
BOILER MATERIALS FOR Ultrasupercritical Coal Power Plants
}

\author{
U.S. DOE NO.: DE-FG26-01NT41175 \\ OCDO NO.: D-00-20
}

\section{Second Quarterly Report for FY 2006 January 1 - March 31, 2006}

Prepared by

R. Viswanathan

K. Coleman

J. Shingledecker

J. Sarver

G. Stanko

M. Borden

W. Mohn

S. Goodstine

I. Perrin

Submitted by

R. Viswanathan

K. Coleman

April 20, 2006

\section{Participating Organizations}

Alstom Power, Inc. 2000 Day Hill Road

Windsor, CT 06095

McDermott Technology, Inc./

Babcock \& Wilcox Company

1562 Beeson St.

Alliance, $\mathrm{OH} 44601$

Oak Ridge National Labs

1, Bethel Valley Road

Oak Ridge, TN 37831
Riley Power Inc.

5 Neponset Street

Worcester, MA 01615

Electric Power Research Institute (EPRI)

3412 Hillview Avenue

Palo Alto, CA 94303
Foster Wheeler Development Corp. 12 Peach Tree Hill Road Livingston, NJ 07039

The Energy Industries of Ohio, Inc. Park Center One 6100 Oak Tree Boulevard Independence, $\mathrm{OH} 44131$ 


\section{U.S. Department of Energy Disclaimer}

This report was prepared as an account of work sponsored by an agency of the United States Government. Neither the United States Government nor any agency thereof, nor any of their employees, makes any warranty, express or implied, or assumes any legal liability or responsibility for the accuracy, completeness, or usefulness of any information, apparatus, product, or process disclosed, or represents that its use would not infringe privately owned rights. Reference herein to any specific commercial product, process, or service by trade name, trademark, manufacturer, or otherwise does not necessarily constitute or imply its endorsement, recommendation, or favoring by the United States Government or any agency thereof. The views and opinions of authors expressed herein do not necessarily state or reflect those of the United States Government or any agency thereof.

\section{Project Consortium Legal Notice/Disclaimer}

This report was prepared by the Energy Industries of Ohio in consortium with the Electric Power Research Institute, Inc. (EPRI); Alstom Power, Inc; Riley Power Inc.; Babcock \& Wilcox/McDermott Technology, Inc.; and Foster Wheeler Development Corporation pursuant to a Grant partially funded by the U.S. Department of Energy (DOE) under Instrument Number DE-FG26-01NT41175 and the Ohio Coal Development Office/Ohio Air Quality Development Authority (OCDO/OAQDA) under Grant Agreement Number CDO/D-00-20. NO WARRANTY OR REPRESENTATION, EXPRESS OR IMPLIED, IS MADE WITH RESPECT TO THE ACCURACY, COMPLETENESS, AND/OR USEFULNESS OF INFORMATION CONTAINED IN THIS REPORT. FURTHER, NO WARRANTY OR REPRESENTATION, EXPRESS OR IMPLIED, IS MADE THAT THE USE OF ANY INFORMATION, APPARATUS, METHOD, OR PROCESS DISCLOSED IN THIS REPORT WILL NOT INFRINGE UPON PRIVATELY OWNED RIGHTS. FINALLY, NO LIABILITY IS ASSUMED WITH RESPECT TO THE USE OF, OR FOR DAMAGES RESULTING FROM THE USE OF, ANY INFORMATION, APPARATUS, METHOD OR PROCESS DISCLOSED IN THIS REPORT.

Reference herein to any specific commercial product, process, or service by trade name, trademark, manufacturer, or otherwise, does not necessarily constitute or imply its endorsement, recommendation, or favoring by the Department of Energy and/or the State of Ohio; nor do the views and opinions of authors expressed herein necessarily state or reflect those of said governmental entities. 


\section{Abstract}

The U.S. Department of Energy (DOE) and the Ohio Coal Development Office (OCDO) have recently initiated a project aimed at identifying, evaluating, and qualifying the materials needed for the construction of the critical components of coal-fired boilers capable of operating at much higher efficiencies than current generation of supercritical plants. This increased efficiency is expected to be achieved principally through the use of ultrasupercritical steam conditions (USC). A limiting factor in this can be the materials of construction. The project goal is to assess/develop materials technology that will enable achieving turbine throttle steam conditions of $760^{\circ} \mathrm{C}\left(1400^{\circ} \mathrm{F}\right) / 35 \mathrm{MPa}$ (5000 psi). This goal seems achievable based on a preliminary assessment of material capabilities. The project is further intended to build further upon the alloy development and evaluation programs that have been carried out in Europe and Japan. Those programs have identified ferritic steels capable of meeting the strength requirements of USC plants up to approximately $620^{\circ} \mathrm{C}\left(1150^{\circ} \mathrm{F}\right)$ and nickel-based alloys suitable up to $700^{\circ} \mathrm{C}\left(1300^{\circ} \mathrm{F}\right)$. In this project, the maximum temperature capabilities of these and other available high-temperature alloys are being assessed to provide a basis for materials selection and application under a range of conditions prevailing in the boiler. This report provides a quarterly status report for the period of January 1 to March 31 , 2006. 


\section{Table of Contents}

Page

ABSTRACT 3

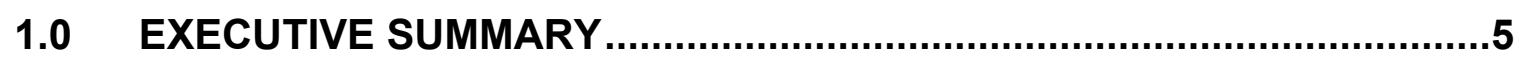

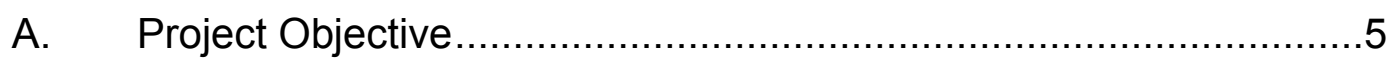

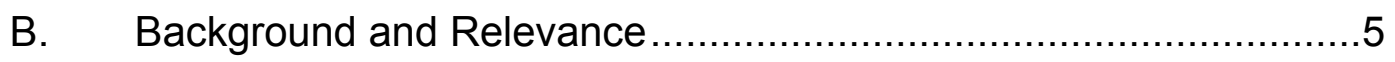

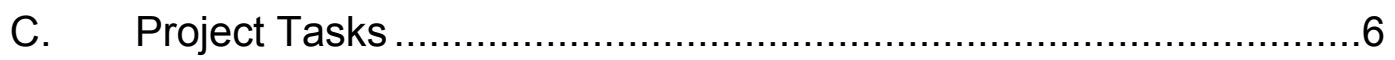

D. Major Accomplishments During the Quarter ...........................6

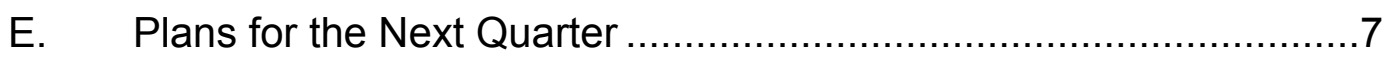

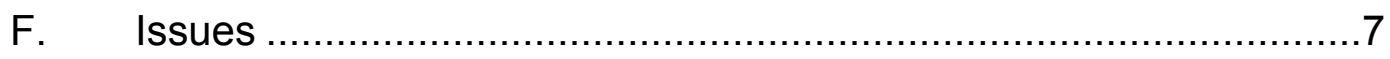

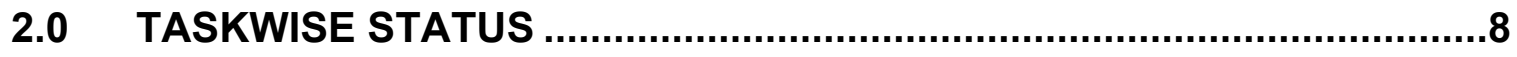

Task 1 Conceptual Design and Economic Analysis.........................

Task 2 Mechanical Properties of Advanced Alloys ...........................11

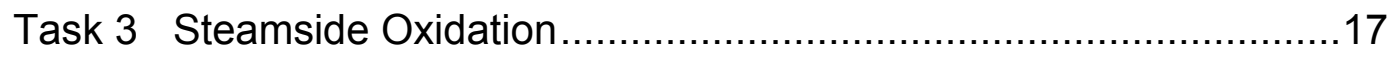

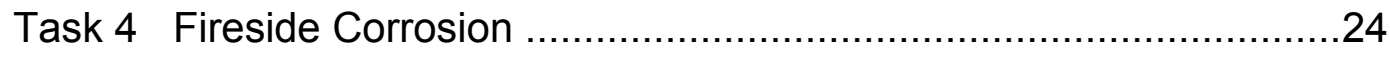

Task 5 Welding Development ..............................................29

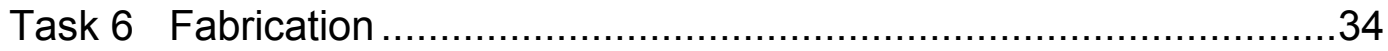

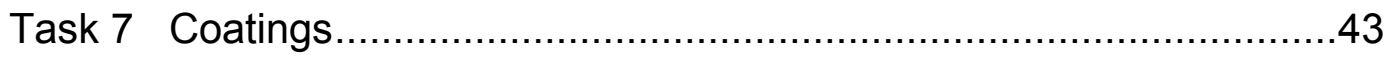

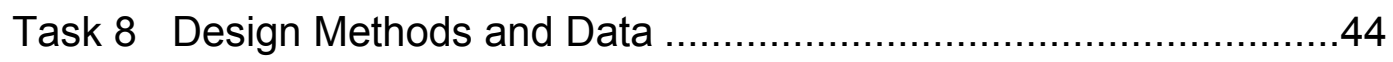

Task 9 Project Integration and Management ...............................49 


\section{Executive Summary}

\section{A. Project Objective}

The principal objective of this project is to develop materials technology for use in ultrasupercritical (USC) plant boilers capable of operating with $760^{\circ} \mathrm{C}\left(1400^{\circ} \mathrm{F}\right), 35 \mathrm{MPa}$ (5000 psi) steam.

\section{B. Background and Relevance}

In the 21st century, the world faces the critical challenge of providing abundant, cheap electricity to meet the needs of a growing global population while at the same time preserving environmental values. Most studies of this issue conclude that a robust portfolio of generation technologies and fuels should be developed to assure that the United States will have adequate electricity supplies in a variety of possible future scenarios.

The use of coal for electricity generation poses a unique set of challenges. On the one hand, coal is plentiful and available at low cost in much of the world, notably in the U.S., China, and India. Countries with large coal reserves will want to develop them to foster economic growth and energy security. On the other hand, traditional methods of coal combustion emit pollutants and $\mathrm{CO}_{2}$ at high levels relative to other generation options. Maintaining coal as a generation option in the 21 st century will require methods for addressing these environmental issues.

This project has established a government/industry consortium to undertake a five-year effort to evaluate and develop of advanced materials that allow the use of advanced steam cycles in coal-based power plants. These advanced cycles, with steam temperatures up to $760^{\circ} \mathrm{C}$, will increase the efficiency of coal-fired boilers from an average of $35 \%$ efficiency (current domestic fleet) to $47 \%$ (HHV). This efficiency increase will enable coal-fired power plants to generate electricity at competitive rates (irrespective of fuel costs) while reducing $\mathrm{CO}_{2}$ and other fuel-related emissions by as much as $29 \%$.

Success in achieving these objectives will support a number of broader goals. First, from a national prospective, the program will identify advanced materials that will make it possible to maintain a cost-competitive, environmentally acceptable coal-based electric generation option. High sulfur coals will specifically benefit in this respect by having these advanced materials evaluated in high-sulfur coal firing conditions and from the significant reductions in waste generation inherent in the increased operational efficiency. Second, from a national prospective, the results of this program will enable domestic boiler manufacturers to successfully compete in world markets for building high-efficiency coal-fired power plants. 
The project is based on an R\&D plan developed by the Electric Power Research Institute (EPRI) that supplements the recommendations of several DOE workshops on the subject of advanced materials. In view of the variety of skills and expertise required for the successful completion of the proposed work, a consortium that includes EPRI and the major domestic boiler manufacturers (Alstom Power, Babcock and Wilcox (a division of McDermott Technologies Inc.), Foster Wheeler, Riley Power Inc., and Oak Ridge National Labs) has been developed.

\section{Project Tasks}

The project objective is expected to be achieved through 9 tasks as listed below:

Task 1. Conceptual Design and Economic Analysis

Task 2. Mechanical Properties of Advanced Alloys

Task 3. Steamside Oxidation Resistance

Task 4. Fireside Corrosion Resistance

Task 5. Welding Development

Task 6. Fabricability

Task $7 . \quad$ Coatings

Task 8. Design Data and Rules

Task 9. Project Integration and Management

\section{Major Accomplishments during the Quarter}

- The creep rupture test matrix for HR6W was completed.

- CCA617 is exceeding expectations in the lower temperature range of $650^{\circ} \mathrm{C}$ to $700^{\circ} \mathrm{C}$.

- Rupture testing of butt-welded HR6W indicated that a weld strength reduction factor will not be required.

- Haynes 230 has demonstrated differences in creep damage after straining.

- Pressurized creep testing of Inconel 740 tube bends has started.

- Thermal shock testing of CCA617 was completed this quarter.

- During the past quarter, it was decided by the Consortium that the final steamside oxidation test should be performed at $750^{\circ} \mathrm{C}\left(1382^{\circ} \mathrm{F}\right)$ instead of $900^{\circ} \mathrm{C}\left(1652^{\circ} \mathrm{F}\right)$.

- Grain size effects on steamside oxidation were evaluated.

- Wastage versus temperature plots for the materials exposed to waterwall fireside corrosion conditions in the laboratory tests were completed. 
- Fabrication and mechanical assembly of the air cooled corrosion probe retraction mechanisms for all three host sites have been completed and data acquisition, instrumentation and control systems development has been completed and tested. The first probe exposure has started.

- Welding procedures were successfully qualified for Inconel 740 using hot wire gas tungsten arc (GTAW-HW) process.

- Two inch bends were successfully completed in Super 304H tubing.

- After forming and exposure to elevated temperature, Super $304 \mathrm{H}$ exhibited relatively stable hardness behavior but that CCA 617 had a pronounced increase in hardness.

- A draft report has been completed on the reference stress method and is currently under review.

\section{E. Plans for the Next Quarter}

It is anticipated that the following work will be completed during the next quarter:

- Continue rupture testing on all materials.

- Low cycle fatigue testing of Haynes 230 will begin.

- $\quad$ Thermal shock testing of Super $304 \mathrm{H}$ will be started.

- One new material (Haynes Alloy 282) and a material processing technology (deep rolling) will be evaluated in the last steamside oxidation test.

- Maintenance work on the steam temperature control system for the steam cooled fire side corrosion test probes will be competed in April.

- Begin tube to tube butt weld procedure qualification trials.

- Continue the analyses of strained and thermally exposed specimens and to assess the data for correlation based on the Larson-Miller parameter

\section{F. Issues}

- HR6W does not demonstrate a creep strength advantage compared to current austenitic tubing.

- ORNL continues to have funding concerns which are impacting the program schedule. 
- The original third host site for the air cooled fireside corrosion probe installation has indicated that their fuel is being changed to $100 \%$ low-sulfur PRB coal. This requires finding a new host site, firing a different coal (possibly Eastern / PRB blend coal). Discussions are under way with to locate another possible host site within Ohio. 


\subsection{Taskwise Status}

\section{Task 1 \\ Conceptual Design and Economic Analysis (Task lead EPRI)}

The objective of Task 1 is to specify the temperature/pressure distribution for $760^{\circ} \mathrm{C} / 35$ $\mathrm{MPa}\left(1400^{\circ} \mathrm{F} / 5000 \mathrm{psi}\right)$ steam inlet conditions so that the data needs and the range of test parameters can be identified and the economics of material selection established.

\section{Task 1A: Alstom Approach (Alstom Power Co.)}

\section{Objectives:}

The primary objectives of this subtask are:

- Develop a conceptual boiler design for a high efficiency ultra supercritical cycle designed for $1400^{\circ} \mathrm{F}$ steam temperature.

- Identify tubing and piping materials needed for high temperature surface construction.

- Estimate gas and steam temperature profiles so that appropriate mechanical, corrosion and manufacturing tests of materials could be designed and conducted to prove suitability of the selected alloys.

\section{Progress for the Quarter}

Topical report issued, task complete.

\section{Task 1B: Babcock Approach}

\section{Objective:}

The objectives of this subtask are the same as in Subtask $1 \mathrm{~A}$.

\section{Progress for the Quarter:}

No work was performed on this task this quarter.

\section{Concerns:}

No concerns at this time.

Progress for the Next Quarter:

Topical report issued, task complete. 


\section{Task 1C: Economic Analysis}

\section{Objective:}

The objective of this task is to determine relative economics of the USC plant.

\section{Progress for the Quarter:}

Topical report issued, task complete. 


\section{Task 2 \\ Mechanical Properties of Advanced Alloys (ORNL)}

The objective of Task 2 is to produce the mechanical properties database needed to design a boiler to operate at the steam conditions within the scope of the project.

\section{Task 2A: Assessment of the Alloy Performance Requirements}

\section{Objectives:}

The primary objectives of this subtask are:

- Focus on performance needed for boiler service in the temperature range of $650^{\circ} \mathrm{C}$ $\left(1200^{\circ} \mathrm{F}\right)$ to $871^{\circ} \mathrm{C}\left(1600^{\circ} \mathrm{F}\right)$.

- Produce reports that justify the materials selected for the pressure retention components of the USC boiler.

\section{Progress for the Task:}

- John Shingledecker gave an invited lecture at North Carolina State University (Materials Science and Engineering Department) in January on high-temperature alloy research at Oak Ridge National Laboratory. The USC Steam Boiler program and some of the ongoing research at ORNL were one of the topics of the lecture. A draft of a paper for the Liege conference was written this quarter and provided to the consortium and sponsors for review and comment. Two new plots of the current state of the creep-rupture testing were also produced (figures 1 and 2) for inclusion in R. Viswanathan's Liege paper.

\section{Task 2B: Detailed Test Plan}

\section{Objectives:}

The detailed mechanical properties test plan is intended to provide guidance on the scope of the mechanical testing for each material to support the resolution of issues related to the tasks undertaken in the project. Categories include: mechanical characterization; data production for the development of code cases; effects of fabrication variables; weldment performance; fatigue and thermal-fatigue behavior; and the like. The six alloys, chemical compositions in Table 1 below, of most interest to the project are: SAVE12, Super 304H, HR6W, Haynes 230, CCA617, and INCONEL 740. Specific heat chemistries are available on the website. 


\section{Progress for the Quarter:}

The characterization testing plans have been completed for the creep-rupture testing of the five tubing alloys (Super 304H, HR6W, alloy 230, CCA617, and INCONEL 740). A test plan for the creep-rupture testing of Inconel 740 plate and SAVE12 pipe have also been produced. Progress and/or problems associated with the welding (Task 5 ) and fabrication (Task 6) tasks will define relevant testing. Thus, to some measure the test plan continues to evolve. The weldment test plan for HR6W is now complete. Test plans for Super $304 \mathrm{H}, \mathrm{CCA} 617$, and Super $304 \mathrm{H}$ to CCA617 tubes have been produced. A test plan to evaluate 740 and 263 weld filler metals on Inconel 740 has been designed and testing has been completed. Thick section weldments plans are being produced as welded material becomes available. Test matrices for verifying and determining the LCF and creep-fatigue behavior of CCA617 and Inconel 740 have been designed and testing initiated. Discussions with Task 8 members have helped define the structural tests needed by the boiler manufacturers to evaluate their respective component models. Notched bar test plans for Inconel 740 have been produced to evaluate the material's notch sensitivity and multi-axial creep behavior.

\begin{tabular}{|c|c|c|c|c|c|c|c|c|c|c|c|c|c|c|c|}
\hline \multirow[b]{2}{*}{ Alloy } & \multirow[b]{2}{*}{$\mathrm{Fe}$} & \multirow[b]{2}{*}{$\mathrm{Cr}$} & \multirow[b]{2}{*}{$\mathrm{Ni}$} & \multirow[b]{2}{*}{$\mathrm{Mn}$} & \multicolumn{7}{|c|}{ Nominal Compositions in $\mathrm{Wt} \%$} & \multirow[b]{2}{*}{$\mathrm{Si}$} & \multirow[b]{2}{*}{$\mathrm{N}$} & \multirow[b]{2}{*}{$\mathrm{Cu}$} & \multirow[b]{2}{*}{ Other } \\
\hline & & & & & Mo & $\mathrm{Ti}$ & $\mathrm{Nb}$ & w & $\mathrm{V}$ & $C$ & $\mathrm{~B}$ & & & & \\
\hline SAVE $12^{\star}$ & bal & 11.0 & & 0.2 & & & & 3.00 & 0.20 & 0.10 & & 0.3 & 0.04 & & $\begin{array}{l}3.0 \mathrm{C} \\
0.07 \mathrm{Ta} \\
0.04 \mathrm{Nd}\end{array}$ \\
\hline Super $304 \mathrm{H}^{*}$ & bal & 180 & 90 & 0.8 & & & 040 & & & 0.10 & & 0.2 & 0.10 & 300 & \\
\hline $\mathrm{HR} 6 \mathrm{~W}^{*}$ & bal & 230 & 43.0 & 12 & & 0.08 & 018 & 600 & & 0.080 & 0.03 & 0.4 & & & \\
\hline Haynes $230^{*}$ & 3.0 & 22.0 & bal & 0.5 & 2.0 & & & 14.00 & & $\begin{array}{l}0.10 \\
\end{array}$ & 0.02 & 0.4 & & & $\begin{array}{c}5.0 \mathrm{Co} \\
0.3 \mathrm{Al} \\
0.02 \mathrm{La}\end{array}$ \\
\hline CCA617 & 0.6 & 21.7 & bal & 0.03 & 8.6 & 0.40 & & & & $\begin{array}{ll}0.05 \\
\end{array}$ & 0.002 & 0.1 & 0.01 & 0.01 & $\begin{array}{r}11.25 \mathrm{Co} \\
1.25 \mathrm{Al}\end{array}$ \\
\hline INCONEL 740 & 2 & 24.0 & bal & 0.3 & 0.5 & 2.0 & 2.0 & & & 0.07 & 0.002 & 0.5 & & & $\begin{array}{r}19.8 \mathrm{Co} \\
0.8 \mathrm{Al} \\
0.015 \mathrm{Zr}\end{array}$ \\
\hline
\end{tabular}

\section{Task 2C: Long Term Creep Strength}

\section{Objectives:}

The primary objectives of this subtask are:

- Identify the general characteristics of the creep behavior and damage accumulation in the candidate alloys.

- Verify the creep-strength of code-approved alloys.

- Assess the creep-strength non code-approved alloys; and provide creep/creeprupture data for a code case if deemed appropriate by consortium members. 
- Provide accurate creep data (i.e. creep-curves) for boiler design on the candidate materials.

\section{Progress for the Quarter:}

The creep-rupture test matrix for the HR6W tubing is now complete. The results confirm earlier predictions based off short-term data which indicated that the HR6W did not have a creep strength advantage compared to current austenitic boiler tubing (see figure 1). Sumitomo has contacted ORNL to provide material from a new 'high creep strength' heat of HR6W in early FY2006. ORNL has asked for the mechanical properties data to evaluate the strength of the alloy before agreeing to more testing. As of March 31, 2006, Sumitomo has not responded to ORNL's request. The CCA617 alloy is exceeding expectations in the lower temperature regime $\left(650^{\circ} \mathrm{C}\right.$ to $\left.700^{\circ} \mathrm{C}\right)$, based on performance equivalent to alloy 617 (see figure 2). Three creep tests have now exceeded 24,000 hours for CCA617. Microstructural studies suggest this strength difference is due to the precipitation of gamma prime at 700 to $800^{\circ} \mathrm{C}$. Larson-MillerParameter extrapolation shows the creep strength benefit may extend to $730^{\circ} \mathrm{C}$ for CCA617 vs. std. 617. All of the planned Super $304 \mathrm{H}$ tests continue. Testing is also progressing on the INCONEL 740 tubing and plate. There exist some differences between the heats and heat treatments as well as differences with the AD700 reported data (figure 2). The longest test times have reached approximately 8,000 hours and lower stress tests have been added to the matrix with expected rupture lives of 10,000 to 20,000 hours. All of these data have been updated on the website this quarter.

\section{Task 2D: Microstructural Analysis}

\section{Objective:}

The primary objectives of this subtask are:

- Identify the microstructural changes that lead to significant changes in the strengthening, weakening, and internal damage characteristics of each material.

- Explore how these changes relate to the exposure conditions of the testing.

\section{Progress for the Quarter:}

A meeting with the University of Cincinnati, subcontract with ORNL to provide electron microscopy studies on aged and creep tested material, is scheduled for next quarter. Recent results will presented at the next steering committee meeting. 


\section{Task 2E: Assessment of Creep-Fatigue Properties}

\section{Objective:}

The primary objectives of this subtask are:

- Verify the low cycle fatigue, creep-fatigue, and thermal mechanical fatigue properties of the thick section alloys.

- Develop a database that will lead to practical, yet conservative methods for new materials.

- Address the issue of creep-fatigue in the boiler materials.

\section{Progress for the Quarter:}

LCF testing on Inconel 740 (Heat \#BLT2819 - plate) continued this quarter beond original expectations for the low strain ranges. A test with a total strain range of $0.3 \%$ $(0.001 / \mathrm{sec}, \mathrm{R}=0)$ has excceded $1 \times 10^{\wedge} 6$ cycles.

\section{Task 2F: Modeling of Weld Joints}

\section{Objectives:}

The primary objectives of this subtask are:

- Produce the experimental data needed to model dissimilar metal and thick-section weld joints.

\section{Progress for the Quarter:}

- Rupture testing is complete on HR6W butt-welded tubes. The results confirmed that the HR6W was weaker than the 82 and 617 weldments. Thus by overmatching the weld metal, HR6W does not require a weld stress reduction factor. Creep-rupture testing continues on Haynes $\circledast 230$ plate weldments. A weld strength factor of 0.8 ( $80 \%$ of base metal strength) has been observed for the various GTAW weldments made in the tube and thin plate.

- Short-term cross-weld creep-rupture testing has been completed on a 5/8" thick Inconel 740 plate welded with both 740 and 263 filler metal. Based on the rupture results, the 263 weld metal creep-rupture strength is greater than that of the 740 . $B \& W$ has indicated that oxidation of the 740 weld metal during welding was an issue that may affect the composition of the weld metal. Proper choice of cover gas has resolved this issue. All ruptures were in the weld metal irrespective of weld metal 
type. Microstructure studies are ongoing to understand the differences in creep strength.

- Testing is ongoing for the large cross-weld specimens from the SAW and SMAW CCA617 2" thick plate weldments. The SMAW appears to be performing better in creep than the SAW. It has been suggested that aluminum content in the weld deposit may have a strong influence on creep properties. ORNL has requested Alstom for the as-deposited CCA617 weld metal chemistries.

- Testing of butt-welded tubes of CCA617, Super304H, and CCA617 to Super304H continued this quarter. Initial results on the Super $304 \mathrm{H}$ to CCA617 DMW produced ruptures in the Super $304 \mathrm{H}$ base metal as expected. The 3" thick Haynes 230 weldment has been received, but machining of specimens has not begun due to FY06 funding considerations.

All data and tests were updated on the website this quarter.

\section{Task 2G: Study of Accelerated Test Methods}

\section{Objectives:}

The primary objective of this task is:

- Provide a method to rapidly characterize changes in the strength of candidate materials.

\section{Progress for the Quarter:}

No new materials have been identified for relaxation testing. This task is complete until an evaluation of a new material is needed or Task 8 determines a critical data need.

\section{Task 2H: Model Validation}

\section{Objectives:}

The primary objective of this task is:

- Produce a database that can be used to confirm or validate design rules that are developed in Task 8.

\section{Progress for the Quarter:}

- Microstructural analysis for cavitation and recrystallization of post-test pressurized creep experiments on Haynes 230 U-bends, to evaluate coldwork effects, were initiated this month. The Haynes 230 bends were stopped after testing for 8,000 
hours without rupturing. The bends with the higher cold strain showed more creep deformation compared to the bend with lower strain indicating differences in creep damage.

- Pressurized creep testing of three Inconel 740 tube bends has started. Haynes 230 end caps were welded to the 740 tube bends using Nimonic 263 filler. The welds passed radiographic inspection this quarter. Welding reports were supplied to the welding task for review. Testing is being performed at $800^{\circ} \mathrm{C}$ and 7040 psi. The estimated rupture time for these tests is 10,000 to 20,000 hours. The tube bend with the highest cold strain ruptured this quarter after 2124.4 hours. Figure 3 shows the macro images of the rupture location and of visible cracking on the extrados of the tube.

- $\quad$ Thermal shock testing on a CCA617 tube was completed this quarter. A meeting was held this quarter with Task 8 representatives modeling the experiment. Additional test plans were made, and a Super $304 \mathrm{H}$ thermal shock specimen was fabricated for testing next quarter.

\section{Concerns:}

Decrease in funding for FY06 has impacted some testing activities. A list of potential impacts was presented at the consortium steering committee meeting for review and comment. Current testing activities have not been delayed until FY2007.

\section{Plans for the Next Quarter:}

Creep-rupture testing of all materials will continue. Pressurized creep testing of Inconel 740 tube bends will continue and creep strain measurements will be made. LCF testing will be started for Haynes 230 from the 3" thick plate. Testing of weldments, including the thick section welds of the CCA617, will continue. Thermal shock testing of Super $304 \mathrm{H}$ will start. 


\section{Task 3 \\ Steamside Oxidation \\ $(\mathrm{B} \& \mathrm{~W})$}

\section{Task 3A: Autoclave Testing}

\section{Background:}

Steamside oxidation tests will be performed on commercially available and developmental materials at temperatures between $650^{\circ} \mathrm{C}$ and $900^{\circ} \mathrm{C}\left(1202^{\circ} \mathrm{F}-1652^{\circ} \mathrm{F}\right)$.

\section{Experimental:}

During the past quarter, it was decided by the Consortium that the final steamside oxidation test should be performed at $750^{\circ} \mathrm{C}\left(1382^{\circ} \mathrm{F}\right)$ instead of $900^{\circ} \mathrm{C}\left(1652^{\circ} \mathrm{F}\right)$. Also, some additional analyses were performed on the descaled weight loss results and on the grain size of iron-based austenitic stainless steels.

\section{- Preparations for $750^{\circ} \mathrm{C}$ Test}

In order to produce test data that will directly correlate with the anticipated USC operating conditions, the Consortium decided at the January 2006 Steering Committee meeting to perform the final steamside oxidation test at $750^{\circ} \mathrm{C}$ instead of at $900^{\circ} \mathrm{C}$. The materials that have been selected for this test are shown in Table 1.

Table 1

\begin{tabular}{|c|c|c|c|c|}
\hline \multicolumn{5}{|c|}{ Materials to be Tested in Steam at $\mathbf{7 5 0 ^ { \circ } \mathbf { C }}$} \\
\hline Ferritics & $\mathbf{3 0 0 - S e r i e s ~ A u s t e n i t i c s ~}$ & Other Austenitics & Chromized & Welds \\
\hline VM12 & 304H & Nimonic 263 & ChromizedS304H & Alloy 230 Weld \\
\hline MARB2 & 347HFGTube & CCA617 & SiChromizedS304H & CCA617 Weld \\
\hline P92 & Shot Blasted 347HFGTube & Alloy 230 & AlChromizedS304H & Alloy 740 Weld \\
\hline SAVE12 & SUPER304H & Alloy 740 & & \\
\hline & SUPER304H Tube & HR120 & & \\
\hline & Shot Blasted & $2025 N b$ & & \\
& SUPER304HTube & SAVE25 & & \\
\hline & 310HCbN & HR6W & & \\
\hline & Deep Rolled 347HFG & RA602CA & & \\
\hline & & Alloy 214 & & \\
\hline & & Alloy 282 & & \\
\hline
\end{tabular}

The Deep Rolled 347HFG was prepared by Ecoroll from a tube segment provided by $B \& W$. Ecoroll performed two different levels of deep rolling; one at each end of the tube segment. Both deep rolling levels will be tested. A new alloy developed by Haynes (Alloy 282: Ni-19.6Cr-10.4Co-8.6Mo-2.2Ti-1.4Al-0.4Fe-0.07C) will also be included in the $750^{\circ} \mathrm{C}$ test series. 
The test specimen preparations for the $750^{\circ} \mathrm{C}$ test are nearly complete, and final facility preparations are underway. It is anticipated that the first exposure period (1,000 hours) will begin in late April.

\section{- Corrosion Rates}

During the January 2006 Steering Committee meeting, the Consortium requested that steamside corrosion rates be calculated. The driving force for this request was to determine the thickness loss that the various materials were experiencing during the steamside oxidation tests, and to arrive at an "acceptable" corrosion rate.

The calculation of corrosion rate in mils per year (mpy) provides a well established method for evaluating thickness loss. While the corrosion rate has been calculated from all of the descaled coupons tested at B\&W since the inception of this program, oxidation rates and oxidation kinetics calculations have received essentially all of the attention. The calculated corrosion rate describes the amount of thickness loss that would be expected based on the data that has been collected. In general, the calculated corrosion rate of a material is high after a short exposure, but drops rapidly until a steady-state corrosion rate is attained. The length of time required to achieve steadystate depends on the material and the environment.

It was observed that $9 \% \mathrm{Cr}$ ferritics that oxidized readily (P91, P92 and SAVE12) displayed corrosion rates that were between one and two orders of magnitude higher than the rest of the materials tested at $650^{\circ} \mathrm{C}$ and $800^{\circ} \mathrm{C}$. The MARB2 (Abe) and VM12 ferritic materials displayed corrosion rates that were only slightly higher than the austenitic materials at $650^{\circ} \mathrm{C}$. At $800^{\circ} \mathrm{C}, \mathrm{MARB} 2$ and VM12 exhibited corrosion rates that were only slightly higher than Ni-based austenitic materials, but significantly lower corrosion rates than most Fe-based austenitic materials due to the oxide exfoliation experienced by the Fe-based austenitics.

Compared to the fireside corrosion rates determined in Task 4, it certainly appears that the steamside corrosion rate will not be the controlling factor in determining the required wall thickness of SH tubing. However, it must be noted that the calculated steamside corrosion rates do not take into account grain boundary oxide penetrations, or the effect of major exfoliation events on the long-term corrosion rates that would be exhibited by these materials.

From the results of this short analysis, it certainly appears that the overriding concern associated with steamside oxidation is the oxide that is formed. Partial exfoliation of this oxide (particularly in $9 \% \mathrm{Cr}$ ferritics) has been shown to isolate areas of tubing and lead to localized overheating. Oxide exfoliation from $<19 \% \mathrm{Cr}$ iron-based austenitics can lead to bend plugging and eventual tube failure, and exfoliated oxide that is entrained in the steam can erode the turbine blades. Thus, while it is important to take into account the wall loss associated with steamside oxidation for design purposes, the principal 
focus of Task 3 must remain on evaluating the oxidation characteristics of candidate USC materials, and the conditions under which these oxides exfoliate.

\section{- Grain Size of Fe-based Austenitics}

To further explain the steamside oxidation behavior of Fe-based austenitic materials, and determine how grain size may be influencing this behavior, B\&W was requested to determine the grain size of the Fe-based austenitic materials that have been tested in this program. Tested and descaled specimens were selected for this evaluation. The results from this analysis did not reveal significant differences in grain size between shot blasted and non-shot blasted materials. Also, the grain size of $347 \mathrm{HFG}$ tubing was essentially equivalent to that of SUPER304H tubing. The grain size of both of these materials was somewhat smaller than that of standard $304 \mathrm{H}$ tubing material.

\section{Concerns:}

No concerns at this time.

\section{Plans for the Next Quarter:}

The first exposure at $750^{\circ} \mathrm{C}(1,000$ hours $)$ will be conducted.

\section{Task 3B Coating Tests}

\section{Background:}

Coated specimens for steamside oxidation testing will be prepared in conjunction with Task 7 and evaluated after testing.

\section{Experimental:}

Chromized, silicon-chromized and aluminum-chromized SUPER304H specimens that were prepared by Alstom will be included in the $750^{\circ} \mathrm{C}$ test. These specimens are prepared and ready for pre-test cleaning, weighing and dimensioning.

\section{Concerns:}

No concerns at this time.

\section{Plans for the Next Quarter:}

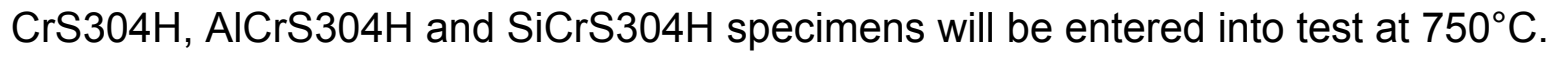




\section{Task 3C Assessment of Temperature}

\section{Background:}

Based on the steamside oxidation test results, the practical temperature limits for the materials tested will be determined.

\section{Experimental:}

Activation energies from $\mathrm{B} \& \mathrm{~W}$ and $\mathrm{ORNL}$ data have been previously reported. Additional data from the $750^{\circ} \mathrm{C}$ tests will be included in the calculation of activation energy when results become available.

\section{Concerns:}

No concerns at this time.

\section{Plans for the Next Quarter:}

Activation energies will be re-calculated following the $750^{\circ} \mathrm{C}$ exposures.

\section{Task 3D Review of Available Information \& Reporting}

\section{Background:}

Available steamside oxidation literature pertaining to materials and environmental conditions of interest will be reviewed. Project status updates will be prepared and status meetings will be attended as required.

\section{Experimental:}

Monthly status reports were prepared for January and February, 2006. A Quarterly Report was prepared for October - December, 2005. A Steering Committee Meeting was attended in Charlotte, NC in January, 2006 where Task 3 results were presented.

\section{Concerns:}

No concerns at this time. 


\section{Plans for the Next Quarter:}

Monthly status reports will be written for April and May, 2006. A Quarterly Report will be written for April - June, 2006. A Steering Committee Meeting will be attended in Cleveland, $\mathrm{OH}$ in May, 2006.

\section{Task 3E Conduct Experimental Exposures}

\section{Background:}

The steam oxidation behavior of model Fe-Cr alloys will be evaluated.

\section{Experimental:}

$\mathrm{B} \& \mathrm{~W}$ is remaining cognizant of the ORNL tests on these model alloys.

\section{Concerns:}

No concerns at this time.

\section{Plans for the Next Quarter:}

BWRC will maintain cognizance of ORNL results. 


\section{Task 3F Characterization}

\section{Background:}

Samples of the model Fe-Cr alloys fabricated in Task 3E will be characterized before and after steamside oxidation testing using metallographic and electron optic techniques.

\section{Experimental:}

None.

\section{Concerns}

No concerns at this time.

Plans for the Next Quarter:

No plans at this time.

\section{Task 3G Data Analysis and Coordination}

\section{Background:}

The steamside oxidation results will be evaluated to determine the effects of material properties and environmental factors on oxidation behavior.

\section{Experimental:}

No progress will be possible until the steamside oxidation tests have been completed (GFY2006).

\section{Concerns:}

No concerns at this time.

\section{Plans for the Next Quarter:}

No plans at this time. 
Milestone Chart:

Dates are listed in GFY.

\begin{tabular}{|c|c|c|c|c|c|c|c|c|}
\hline \multirow[t]{2}{*}{ ID } & \multirow[t]{2}{*}{ Task Name } & 2002 & 2003 & 2004 & 2005 & \multicolumn{2}{|c|}{2006} & 2007 \\
\hline & & \begin{tabular}{|l|l|l|l|} 
Q1 & Q2 & Q3 & Q4 \\
\end{tabular} & \begin{tabular}{|l|l|l|l|} 
Q1 & $Q 2$ & $Q 3$ & $Q 4$ \\
\end{tabular} & \begin{tabular}{|l|l|l|l|} 
Q1 & Q2 & Q3 & Q4 \\
\end{tabular} & \begin{tabular}{|l|l|l|l|} 
Q1 & Q2 & Q3 & Q4 \\
\end{tabular} & \begin{tabular}{|l|l|}
$Q 1$ & $Q 2$ \\
\end{tabular} & \begin{tabular}{|l|l|} 
Q3 & Q4 \\
\end{tabular} & \begin{tabular}{|l|l|l|l|} 
Q1 & Q2 & Q3 & Q4 \\
\end{tabular} \\
\hline 1 & 3A Autoclave Testing & & & & & & & \\
\hline 2 & Design, Build \& Test Facility & "I & $100 \% \mathrm{Co}$ & omplete & & & & \\
\hline 3 & Procure \& Characterize Materials & & $100 \% \mathrm{Cc}$ & implete & & & & \\
\hline 4 & Design \& Build Test Sections & & $100 \% \mathrm{Cc}$ & omplete & & & & \\
\hline 5 & Perform 4000 hr Test @ 650 \& Evaluate & & & $100 \% \mathrm{c}$ & omplete & & & \\
\hline 6 & Perform 4000 hr Test @ 800 \& Evaluate & & & 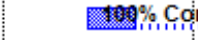 & mplete & & & \\
\hline 7 & Perform 4000 hr Test @ 900 \& Evaluate & & & & $20 \%$ Com & nplete & & \\
\hline 8 & 3B Coating Tests & & & & & & & \\
\hline 9 & Prepare Coupons & & 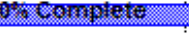 & & & & & \\
\hline 10 & Post-test Evaluation & & & 67\% & plete & ， & & 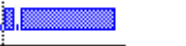 \\
\hline 11 & 3C Assessment of Temperature & & & & & & & \\
\hline 12 & Compile and Analyze Test Data & & & $67 \%$, Con & Pleste, & , 圈 $\ldots \ldots \ldots$ & & 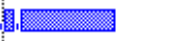 \\
\hline 13 & Determine Material Temp Limits & & & & & & & 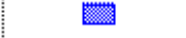 \\
\hline 14 & 3D Literature Review \& Reporting & & & & & & & \\
\hline 15 & Literature Review & $100 \%$ crmanter & & & & & & \\
\hline 16 & Monthly Updates & |||||||||| $\mid$ & $\|1\| 1|||||| \mid$ & $\| 1111111111$ & $\|1\|\|\|\|\| \|$ & $|1| 1||$ & 11111 & |||||| $\mid$ \\
\hline 83 & Quarterly Updates & $1 \quad 1 \quad 1$ & $1 \quad 1 \quad 1$ & $1 \quad 1 \quad 1$ & $1 \quad 1 \quad 1$ & I & I & I \\
\hline 106 & Meetings & 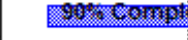 & & & & & & \\
\hline 107 & 3E Model Fe-Cr Alloys & & & & & & & \\
\hline 108 & Cognizance of ORNL Activities & 900 & tere & & & & & \\
\hline 109 & 3F Characterize Model Fe-Cr Alloys & & & & & & & \\
\hline 110 & Cognizance of ORNL Activities & $90+60 \%$ & Fete & & & & & \\
\hline 111 & 3G Data Analysis & & & & & & & \\
\hline 112 & Compile \& Analyze Data & & & & & & & \\
\hline 113 & Determine Rate Laws vs. Composition & & & & & & & \\
\hline
\end{tabular}




\section{Task 4 \\ Fireside Corrosion (Foster Wheeler)}

The objective of the task is to evaluate the relative resistance of various advanced alloys for waterwall and reheater/superheater construction to fireside corrosion over the full temperature range expected for the USC plant. The corrosive environment promoted by three different coals, representative of an eastern coal, a midwestern coal, and a western coal, will be evaluated.

\section{Task 4A: Laboratory Testing}

\section{Objective:}

The objective of this sub-task is to perform laboratory corrosion tests on the candidate alloys. This will be accomplished by exposing metal coupons to various deposits and flue gases representative of three coals (e.g., eastern, midwestern, and western) at the range of temperatures expected for the USC plant.

\section{Experimental:}

During the quarter, wastage versus temperature plots for the materials exposed to waterwall conditions in the laboratory tests were completed. The data from the laboratory tests on both superheater/reheater and waterwall materials are being analyzed in preparation for final report.

\section{Concerns:}

None.

\section{Plans for Next Quarter:}

Continue to refine the results of the laboratory tests.

\section{Task 4B Corrosion Probe Testing in Utility Boilers}

\section{Objective:}

The objective of this sub-task is to install corrosion probes comprised of various alloys/coatings/weld overlays at three coal-fired power plants and control them in the temperature range expected for reheater/superheater components in the USC plant. The plants should burn coals representative of the three types specified earlier. 


\section{Experimental Progress:}

- Fabrication and mechanical assembly of the probe retraction mechanisms for all three host sites have been completed.

- Data acquisition, instrumentation and control systems development has been completed and tested.

- First pair of of corrosion probes has been installed in a Mid-Western host utility site during January 2006. Exposures for the one-year and two-year probes are ongoing. Figure 4.1 shows the 2-year probe, in the extended position. Figure 4.2 shows a close-up view of the same probe, in the retracted position, in which the sample segments are visible.

- Second pair of corrosion probes has been prepared for installation at a Western utility host site. Critical components have been delivered to the second host site. Probe installation tasks are ongoing, and will be completed once the electrical and mechanical on-site work needed to accommodate the new installation has been performed.

- Material samples for the third pair of probes have been machined and assembled. Deployment of the third pair of probes is pending signing of the host agreement by an Ohio utility..

- Foster Wheeler continues to work closely with the host utility personnel to coordinate continuing exposures, and installation activities, as needed..

- Changes in fuel at our original Eastern coal host site have necessitated locating a new host site. Several discussions were held with a new plant in Ohio to replace the original third host site. Home office and plant personnel have generally agreed to host the third pair of corrosion probes. Final determination should be made shortly. 


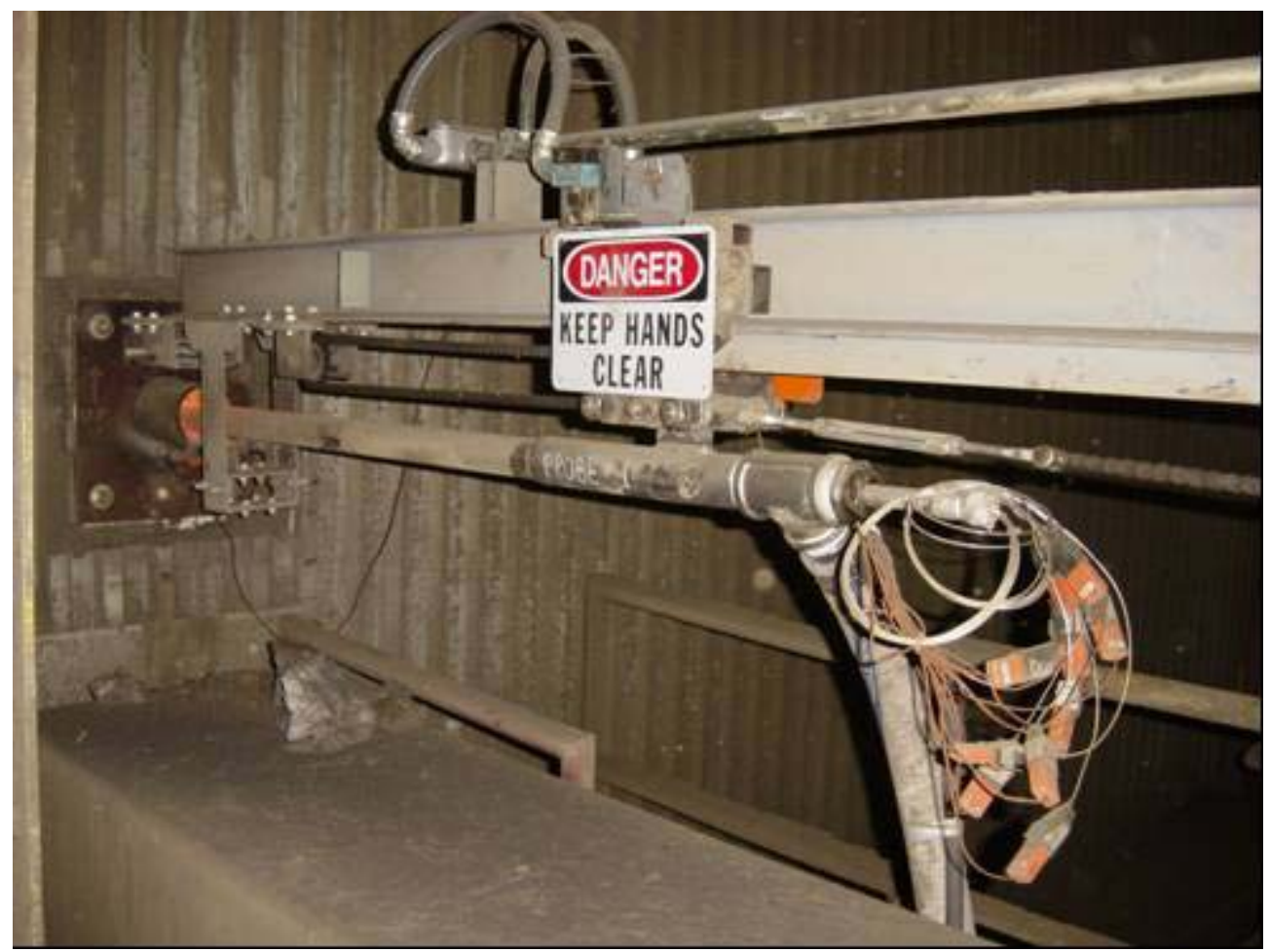

Figure 1 - Corrosion Probe Operating at Mid-western Utility

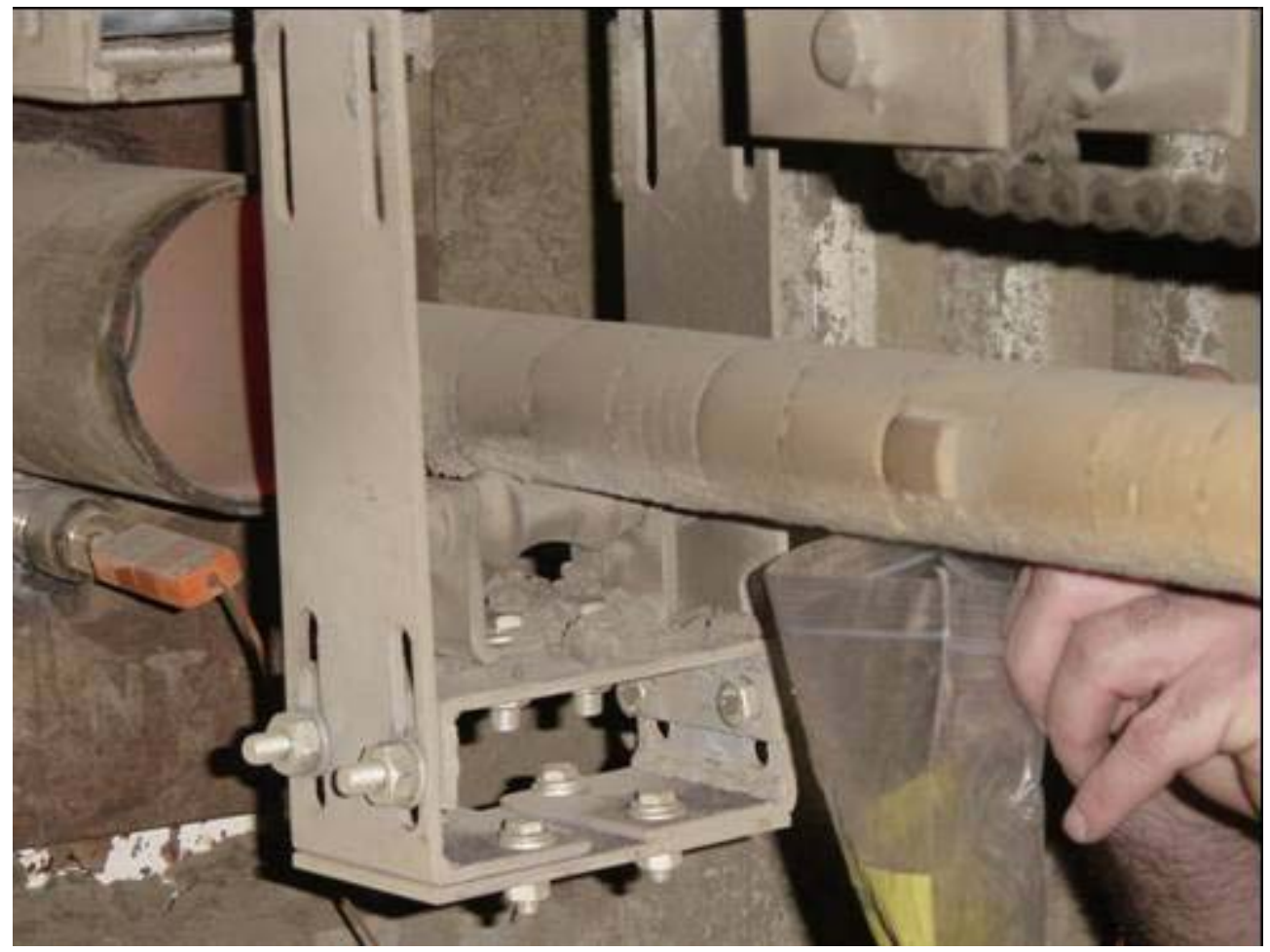

Figure 2 - Close-up View Corrosion Probe Installed at Mid-western Utility 


\section{Concerns:}

The original third host site has indicated that their fuel is being changed to $100 \%$ lowsulfur PRB coal. This requires finding a new host site, firing a different coal (possibly Eastern / PRB blend coal). Discussions are under way with AEP to locate another possible host site within Ohio.

\section{Plans for Next Quarter:}

- Monitor ongoing exposures at the installed probe sites.

- Finalize hosting arrangements and logistics for third host site.

- Complete site installation tasks, coordinating with host utilities.

- Complete mechanical and electrical modifications at $2^{\text {nd }}$ and $3^{\text {rd }}$ host sites.

- Continue site installation tasks, coordinating with host utilities.

- Install probes at remaining host sites.

\section{Task 4C Steam Loop Design, Construction, and Testing}

\section{Objectives:}

The objectives of this sub-task are to design, build, and test an experimental USC steam loops that will operate in a commercial boiler at metal temperatures up to $1400^{\circ} \mathrm{F}$. The elements of this subtask include the following:

- Design and construct the test loop using commercially-available, high-temperature corrosion-resistant alloys selected for the USC Plant.

- Install and operate the test loop at the Reliant Electric power plant, which is located in Niles, $\mathrm{OH}$ and is burning high sulfur Ohio coal.

- Test and monitor the relative performance of the USC tube alloys, coatings, claddings, and weld overlays, which comprise the test loops, for a period of 18 to 24 months.

\section{Experimental:}

Vendors are being arranged for the schedule April outage for overhauling the control and shut-off valves in order to increase system reliability. Preparations are being made to restore some damaged thermocouples during the outage. The outage work is intended to significantly improve the reliability of the system to enable the loops to operate at full temperature for the duration of the program (at least until next fall). Niles 
has agreed to extend the end date due to previous problems with the valves, which resulted in loss of significant amount of time at temperature.

\section{Plans for the Next Quarter:}

- When the outage begins, B\&W will meet with the valve vendors to inspect and determine repairs and decide how to proceed.

- Arrangements will be made to perform the valve refurbishment.

- Failed thermocouples will be repaired or replaced. 


\section{Task 5 \\ Welding Development \\ (Alstom)}

\section{Objectives:}

- To define weld metal choices for candidate materials.

- To establish acceptable welding procedures and practices.

- To evaluate the effects of manufacturing heat treatments and preheat and post weld heat treatments on weldment integrity and properties.

- To produce samples needed to determine the properties of candidate ultrasupercritical alloy welds and weldments, including the dissimilar metal weld joints between the various types of material (the actual mechanical and property testing will be performed under Task 2).

These objectives will be accomplished through execution of five sub-tasks. Where activity on these sub-tasks occurred during the reporting period, it is described below.

\section{Task 5B: Optimization of Weld Parameters}

\section{Objectives:}

The primary objectives of this subtask are to establish the baseline welding parameter values for each material/process/product form combination being studied. Included is the development of preheat and post weld heat treatment requirements.

\section{Progress for the Quarter:}

\section{SAVE 12:}

- The SAVE12 heavy wall (13.78-inch OD x 2.3-inch wall pipe) weld qualification efforts continued with further investigation of the fluxes used for submerged arc welding. Although a thick-section welding process using a flux core fill was qualified, metallurgical examination of the bend specimen surfaces and cross-sections revealed the existence of tungsten and neodymium inclusions and titanium, chromium, and silicon oxides. Since these inclusions and metallic oxides are potentially detrimental to creep rupture properties, the fabrication of weld characterization specimens using the same lot of flux core filler that was used in procedure qualification was not considered advisable and research efforts returned to submerged arc welding as a high deposition rate process. In addition to the flux, the base material and the submerged arc filler wire are being investigated as 
sources of the tramp elements responsible for the inclusions and oxides and a reformulated wire is being planned. Replacement of the base material, should it be a primary source of the elements, would be very difficult.

- Sumitomo advised that both SAVE12 and HR6W will continue to be developed (using the same names) under a Japanese government-supported program called RITE. The latest thinking on SAVE12 aims for a composition similar to that which is being used in the Ultrasupercritical Boiler Materials program, including the $9.25 \%$ chromium rather than the $10.5 \%$ level referenced in some of the literature. Sumitomo recognizes the strength shortfalls of both materials and is aiming to attain the original predictions through compositional refinements.

\section{Inconel 740:}

- Hot wire gas tungsten arc welding tests were conducted on 1.75-inch thick Inconel 740 plates using a $25 \%$ Helium $/ 75 \%$ Argon shielding gas and matching filler wire. The test plates, which were aged after welding, exhibited very few microfissures and passed all of the ASME Section IX bend and tensile tests. This process is now qualified for plates up to 3 inches thick and these efforts represent the thickest section ever qualified for Inconel 740.

- The qualified process was also used to join three-inch thick coupons and the specimen is currently undergoing examination and mechanical testing. Coupons that have been age hardened are being prepared to assess the susceptibility of the base material to cracking while being welded in this condition.

\section{General}

- An abstract and rough draft were prepared for a paper that will be presented on Inconel 740 weldability at the EPRI conference on Welding and Repair Technology for Power Plants in June 2006.

- Efforts to prepare a final comprehensive Task 5 report continued.

\section{Concerns:}

- Submerged arc welding, a high deposition rate process favored by boilermakers for thick sections, does not appear feasible for all nickel base materials. Tests on Haynes 230 and Inconel 740 have been unsuccessful because of cracking and the process is being abandoned on these two alloys.

- The unexpectedly high cost of the nickel base alloys will cause the material budgets to be exceeded and might result in program cost overruns and/or reductions in program scope. 
- The difficulties encountered while attempting to weld HR6W using matching filler metals proved insurmountable for this program and there will be no further effort in this area.

- Inconel 740 appears to have a heat-to-heat sensitivity with regards to microfissuring and this could require additional constraints on composition.

- The use of matching filler metal for welding thick section CCA 617 plates does not appear practical.

\section{Plans for the Next Quarter:}

- Continue with the efforts to qualify the welding of the SAVE 12 thick wall pipe material using a submerged arc process.

- Continue to study the problems with heat affected zone microfissuring in Inconel 740 by making hot wire gas tungsten arc welds in 3-inch thick plate.

- Begin development of Inconel 740 welding procedures for tube butt joints, dissimilar metal welds, attachments, and repairs.

- Continue preparation of final comprehensive report.

\section{Task 5C: Preparation of Laboratory Samples}

\section{Objectives:}

The primary objective of this subtask is to produce multiple samples representing each of the material/process/product form combinations being studied. These samples will be evaluated by ORNL as part of the Task 2 activities.

\section{Progress for the Quarter:}

The two butt weld samples in the 2-inch diameter, 0.4-inch minimum wall thickness SAVE 12 tubing that were prepared using the SAVE 12 custom filler a manual gas tungsten arc process for both the root and fill passes met all test requirements and were shipped to ORNL for testing.

\section{Concerns:}

No concerns at this time. 
Plans for the Next Quarter:

- Using a process that has already been qualified, provide ORNL with a P92 pipe (6.3inch OD x 1.1-inch wall) butt joint sample for testing.

\section{Task 5E: Examination of Dissimilar Metal Welds}

\section{Objectives:}

The primary objectives of this subtask are to develop and study the dissimilar metal welds that would be required to make transitions between the various alloys included in this program and the conventional materials that would also be used in an ultrasupercritical boiler.

\section{Progress for the Quarter:}

- Two dissimilar metal weld samples involving SAVE 12 and HR6W tubing were prepared and sent to ORNL for evaluation. The butt welds in the 2-inch diameter, 0.4 -inch minimum wall thickness tubes utilized Inconel 82 filler and a manual gas tungsten arc process for both the root and fill passes.

- A dissimilar metal weld between T91 and Super 304H was sectioned and prepared for metallurgical examination. No discrepant conditions were detected, which confirmed the results of the weld procedure qualification tests.

\section{Concerns:}

No concerns at this time.

Plans for the Next Quarter:

Fabricate samples of dissimilar metal joints between the HR6W and SAVE12 tubing using only gas tungsten arc welding for testing by ORNL. 
Task 5: Welding Development - Milestone Chart

(DOE Fiscal Year Basis)

\section{(percentages indicate fraction of workscope completed as of 2005Q4)}

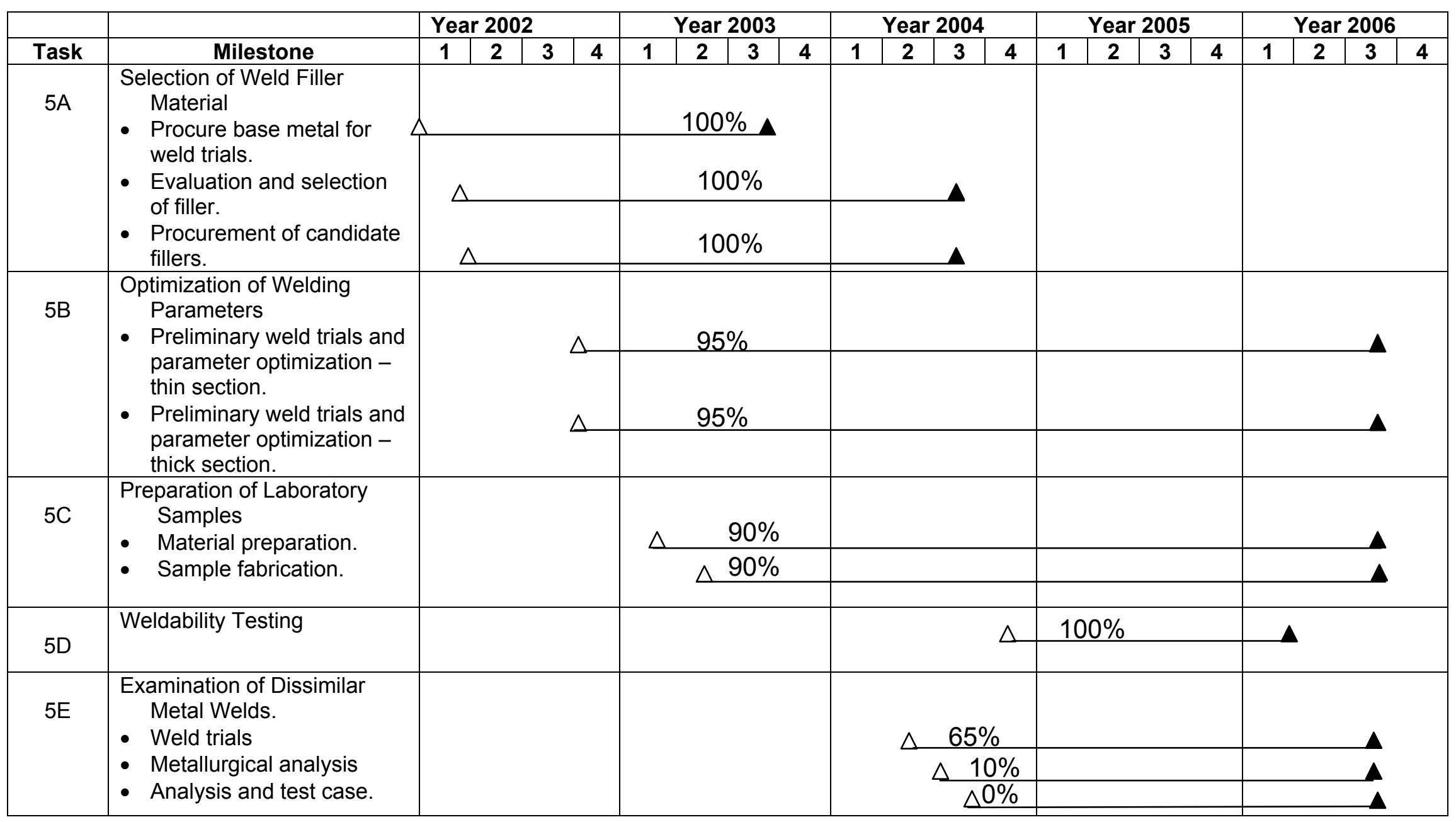




\section{Task 6 \\ Fabrication \\ $(B \& W)$}

\section{Objectives:}

The objective of Task 6 is to establish boiler fabrication guidelines for the high temperature, oxidation and corrosion resistant alloys selected for the USC Project. The principal goals in this joint effort are:

- To establish fabrication guidelines for the high temperature, corrosion resistant alloys needed for boiler components in the USC power plant.

- To determine the thermomechanical treatments or other remedial actions necessary to restore material properties which might degrade due to fabrication operations.

- To investigate prototypical manufacturing operations for producing both thick wall and thin wall components from the USC alloys.

Progress for the Quarter: $\quad$ Riley Power, Inc.

Riley Power has continued the preparation of summary reports on the history and accomplishments of the materials fabricability efforts. The format established by B\&W will be used for the content and assembly of the report.

\section{Concerns:}

No concerns at this time.

\section{Plans for the Next Quarter:}

- After the recrystallization study results are available, Riley Power will determine the appropriate heat treatments applicable to the HR6W and SAVE12 materials, and additional samples of the materials may be sent to ORNL for testing.

- Riley Power Inc. is still considering the fabrication of a mock-up header/spool piece which would contain tubing components and welding of the HR6W and SAVE12 materials.

\section{Progress for the Quarter: $\quad$ Alstom Power, Inc.}

\section{$\underline{\text { U-bend Specimens }}$}

- The initial attempt at making 2-inch radius Super $304 \mathrm{H}$ hot bends was not completely successful in that some folding occurred in the intrados. A second set of bends was made using a revised procedure, which corrected the folding problem.

- Geometric characterizations and destructive examinations were continued and have been completed on the specimens fabricated from both CCA 617 and Super 304H 
tubing. These included 3, 5, and 7 -inch radius cold bends and 3 -inch radius cold bends that were subsequently hot formed to a 2 -inch radius. Preliminary evaluation of the data did not reveal any detrimental conditions.

\section{Tapered Tube Specimens}

- Examination of the tapered tubes used for the cold working studies continued. One aspect of these studies is the hardness variations that occur from cold working and thermal exposure and hardness data that have been obtained on the baseline (no cold working) samples provide information regarding the thermal stability of the materials. Plots of hardness versus time for various exposures are presented below and show that Super $304 \mathrm{H}$ exhibited relatively stable behavior but that CCA 617 had a pronounced increase in hardness at $1400 \mathrm{~F}(760 \mathrm{C})$ and then a return to its original level at higher temperatures. These data would indicate that, although this material is not considered to be precipitation hardening, some hardening (and probably strengthening) is occurring during initial exposure at the lower temperatures and that this condition disappears, due to precipitate coarsening, at higher temperatures. Any precipitation that could be associated with the hardness increases was not discernable with light microscopy but precipitate coarsening was evident in the specimens from the 1500 and 1600F exposures.

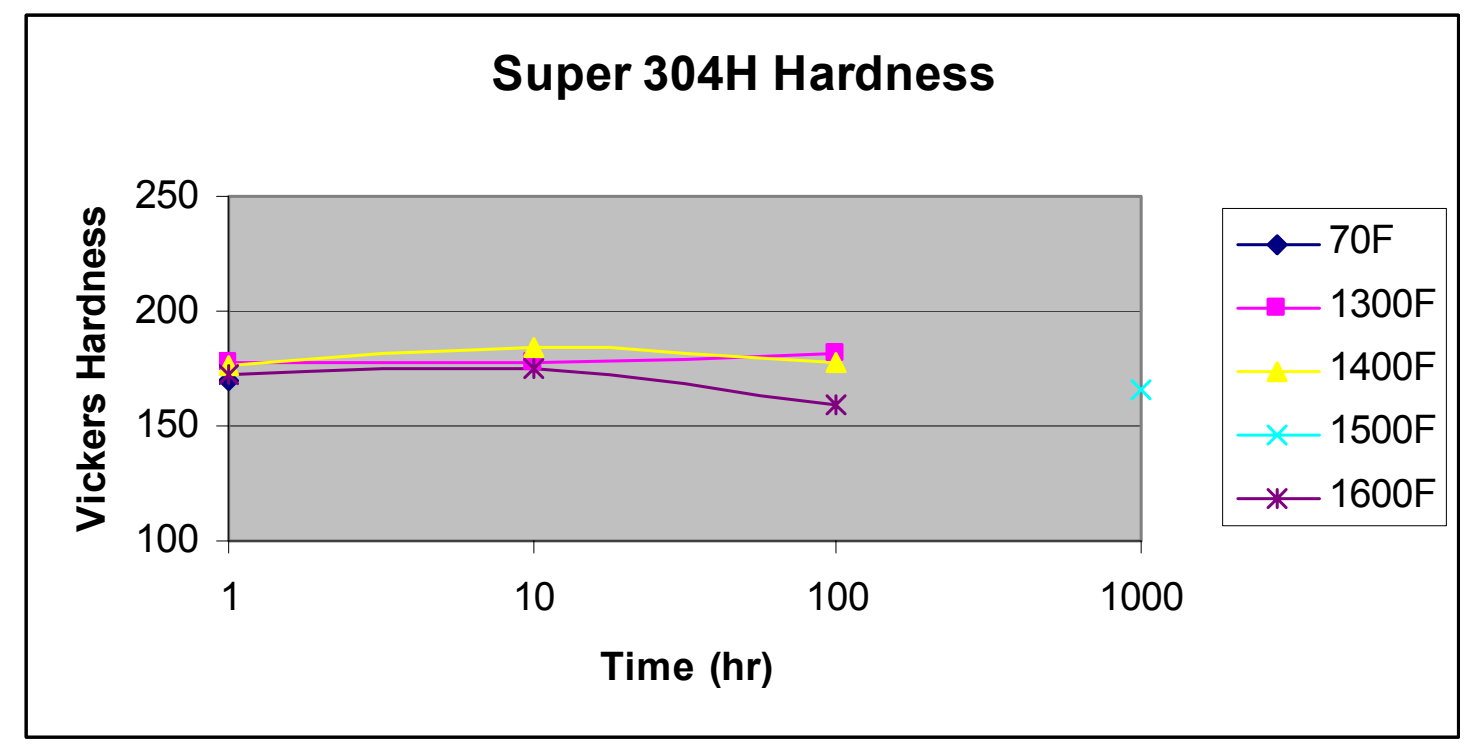

Figure 1 Vickers hardness versus exposure times for Super 304H at different selected temperatures 


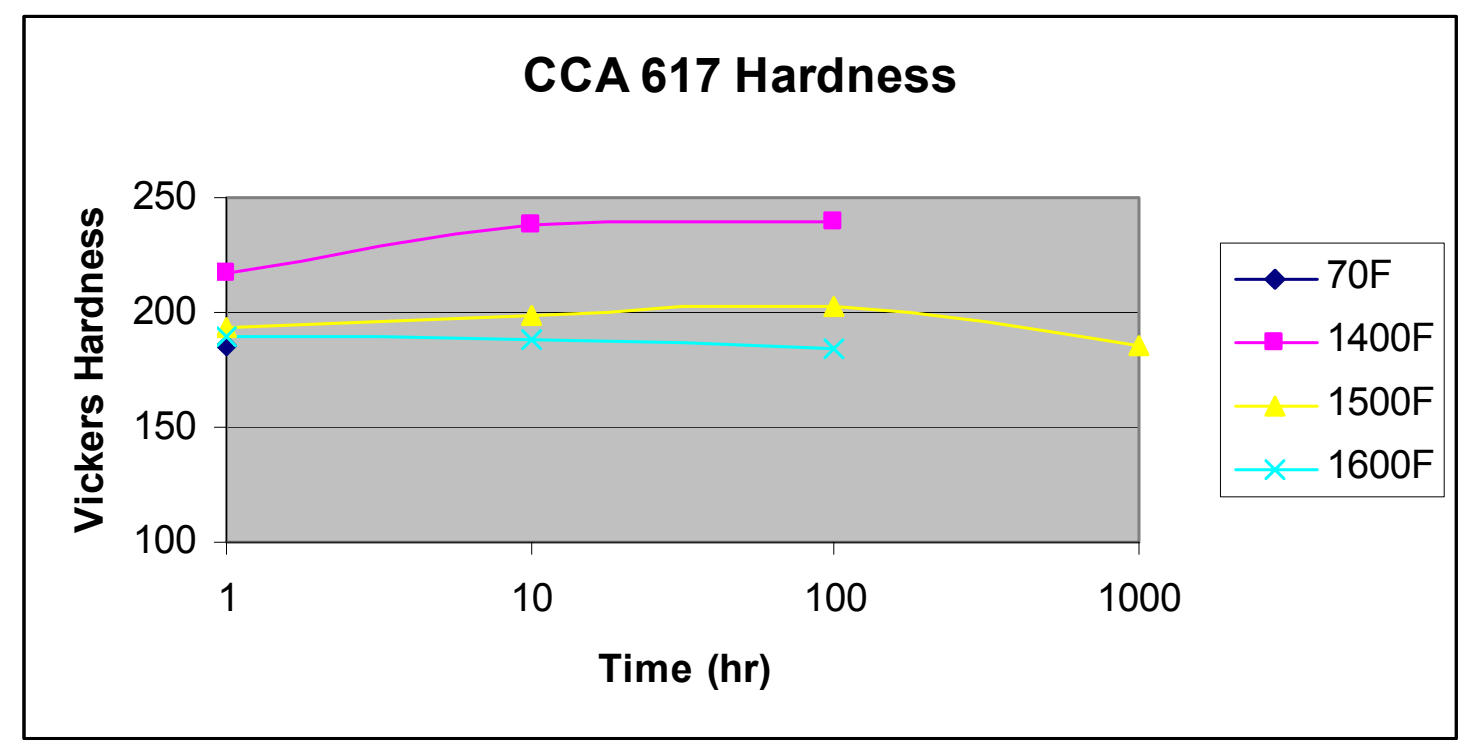

Figure 2 Vickers hardness versus exposure times for CCA617 at different selected temperatures

\section{Concerns:}

No new concerns at this time.

\section{Plans for the Next Quarter:}

- Continue the examination of the tapered tubes used for the cold working studies.

- Determine the sensitivity of Super $304 \mathrm{H}$ to strain induced embrittlement.

\section{Progress for the Quarter: Foster Wheeler}

\section{Fabrication of IN740:}

- Most of the work that was performed involved the analysis of the recrystallization data to determine if there is a relationship between the onset of recrystallization and the Larson-Miller Parameter for the thermal exposures conducted on the strained alloy 230 and HR6W materials. Some of the results of this work are provided below: 


\begin{tabular}{|c|c|c|c|c|c|}
\hline 230 & $\begin{array}{l}\text { OFS Initial } \\
\text { Recrystalliz- } \\
\text { ation }\end{array}$ & 740 & $\begin{array}{l}\text { OFS Initial } \\
\text { Recrystalliz- } \\
\text { ation }\end{array}$ & HR6W & $\begin{array}{l}\text { OFS Initial } \\
\text { Recrystalliz- } \\
\text { ation }\end{array}$ \\
\hline $\begin{array}{l}1500^{\circ} \mathrm{F}-100 \\
\text { hrs. }\end{array}$ & 41.8 & $\begin{array}{l}1500^{\circ} \mathrm{F}-100 \\
\text { hrs. }\end{array}$ & --- & $\begin{array}{l}1400^{\circ} \mathrm{F}-150 \\
\text { hrs. }\end{array}$ & 18.8 \\
\hline $\begin{array}{l}1500^{\circ} \mathrm{F}-700 \\
\text { hrs. }\end{array}$ & 20.5 & $\begin{array}{l}1600^{\circ} \mathrm{F}-100 \\
\text { hrs. }\end{array}$ & --- & $\begin{array}{l}1500^{\circ} \mathrm{F}-100 \\
\text { hrs. }\end{array}$ & 13.9 \\
\hline $\begin{array}{l}1550^{\circ} \mathrm{F}-124 \\
\text { hrs. }\end{array}$ & 25 & $\begin{array}{l}1600^{\circ} \mathrm{F}-1000 \\
\text { hrs. }\end{array}$ & --- & $\begin{array}{l}1600^{\circ} \mathrm{F}-100 \\
\text { hrs. }\end{array}$ & 12.0 \\
\hline $\begin{array}{l}1600^{\circ} \mathrm{F}-100 \\
\text { hrs. }\end{array}$ & 20.5 & & & $\begin{array}{l}1600^{\circ} \mathrm{F}-1000 \\
\text { hrs. }\end{array}$ & 9.0 \\
\hline $\begin{array}{l}1600^{\circ} \mathrm{F}-1000 \\
\text { hrs. }\end{array}$ & 15.5 & & & & \\
\hline $\begin{array}{l}1650^{\circ} \mathrm{F}-12.5 \\
\text { hrs. }\end{array}$ & 23.6 & & & & \\
\hline
\end{tabular}

FIGURE 3 Summary of Thermal Exposures and Outer-Fiber-Strain (OFS) at which initial Recrystallization was apparent 

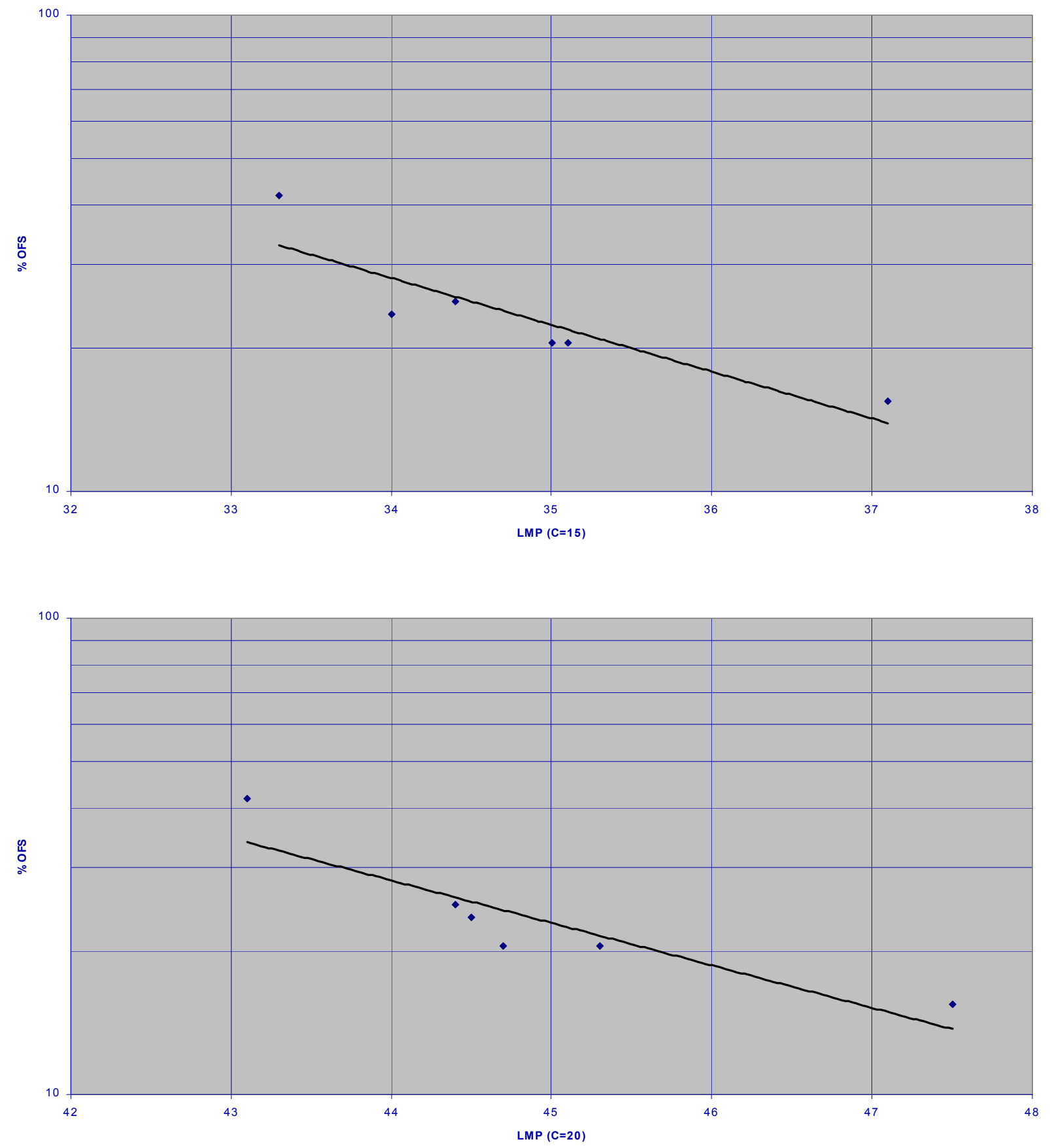

FIGURE 4 LM Curve for Onset of Recrystallization in 230 Material (Top: $C=15$, Bottom: $C=20$ ) 


\section{$30 \%$ OFS}

\begin{tabular}{|c|c|c|}
\hline & \multicolumn{2}{|c|}{ Time (Hrs.) } \\
\hline Temperature $\left({ }^{\circ} \mathrm{F}\right)$ & $\mathbf{C = 1 5}$ & $\mathbf{C = 2 0}$ \\
\hline $1200^{\circ} \mathrm{F}$ & 200,000 & $>1,000,000$ \\
\hline $1300^{\circ} \mathrm{F}$ & 12,000 & 70,000 \\
\hline $1400^{\circ} \mathrm{F}$ & 1,100 & 3,500 \\
\hline $1500^{\circ} \mathrm{F}$ & 120 & 210 \\
\hline
\end{tabular}

\section{$20 \%$ OFS}

\begin{tabular}{|c|c|c|}
\hline & \multicolumn{2}{|c|}{ Time (Hrs.) } \\
\hline Temperature $\left({ }^{\circ} \mathrm{F}\right)$ & $\mathbf{C = 1 5}$ & $\mathbf{C = 2 0}$ \\
\hline $1300^{\circ} \mathrm{F}$ & 148,000 & 900,000 \\
\hline $1400^{\circ} \mathrm{F}$ & 10,000 & 35,000 \\
\hline $1500^{\circ} \mathrm{F}$ & 1,000 & 2,000 \\
\hline
\end{tabular}

FIGURE 5 Table indicating temperature/time combinations where recrystallization may initiate in alloy 230 having $30 \%$ and $20 \%$ OFS 

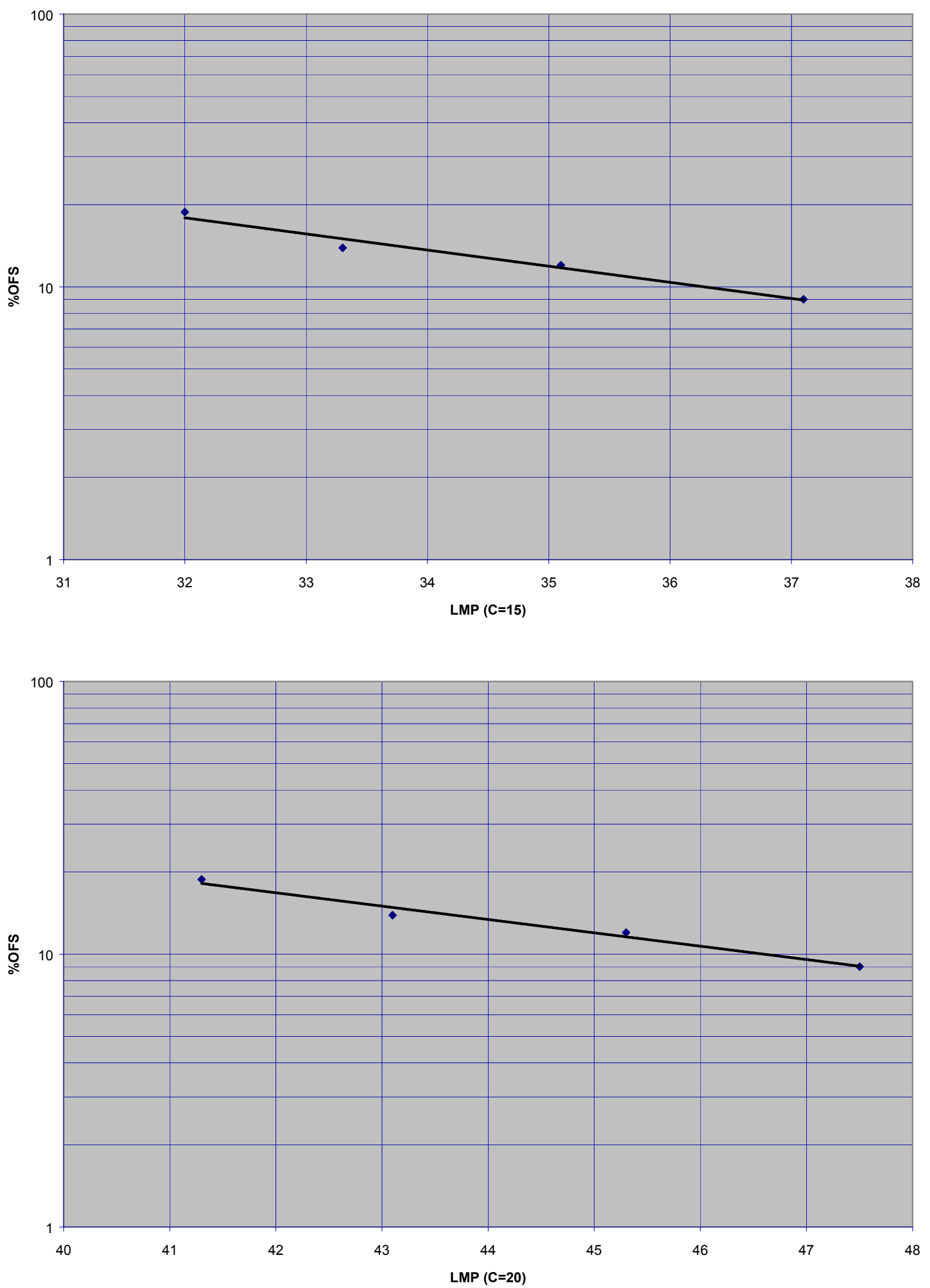

FIGURE 6 LM Curve for Onset of Recrystallization in HR6W Material (Top: $C=15$, Bottom: $C=20$ ) 


\section{$20 \%$ OFS}

\begin{tabular}{|c|c|c|}
\hline & \multicolumn{2}{|c|}{ Time (Hrs.) } \\
\hline Temperature $\left({ }^{\circ} \mathrm{F}\right)$ & $\mathbf{C = 1 5}$ & $\mathbf{C = 2 0}$ \\
\hline $1150^{\circ} \mathrm{F}$ & 28,000 & 190,000 \\
\hline $1200^{\circ} \mathrm{F}$ & 7,000 & 30,000 \\
\hline $1250^{\circ} \mathrm{F}$ & 2,000 & 6,000 \\
\hline $1300^{\circ} \mathrm{F}$ & 600 & 1,200 \\
\hline
\end{tabular}

$15 \%$ OFS

\begin{tabular}{|c|c|c|}
\hline & \multicolumn{2}{|c|}{ Time (Hrs.) } \\
\hline Temperature $\left({ }^{\circ} \mathrm{F}\right)$ & $\mathbf{C = 1 5}$ & $\mathbf{C = 2 0}$ \\
\hline $1200^{\circ} \mathrm{F}$ & 100,000 & $1,000,000$ \\
\hline $1250^{\circ} \mathrm{F}$ & 20,000 & 190,000 \\
\hline $1300^{\circ} \mathrm{F}$ & 8,000 & 35,000 \\
\hline $1350^{\circ} \mathrm{F}$ & 2,500 & 7,000 \\
\hline
\end{tabular}

FIGURE 7 Table indicating temperature/time combination where recrystallization may initiate in HR6W having $20 \%$ and $15 \%$ OFS

\section{Concerns:}

No concerns at this time.

Plans for the Next Quarter:

- Continue the analyses of strained and thermally exposed specimens and to assess the data for correlation based on the Larson-Miller parameter.

Progress for the Quarter: $\quad$ B\&W

- Preparation of B\&W's contribution to the Task 6 final topical report continued.

- The USC Steering Committee meeting was attended January $18^{\text {th }}-19^{\text {th }}$ at EPRI in Charlotte, NC, where Demonstration Article "A" (superheater section) was displayed. 


\section{Concerns:}

Delays in funding have delayed some Task 6 activities (e.g., fabrication of Demonstration Article "B") that were planned for completion this quarter.

\section{Plans for the Next Quarter:}

- Preparation of B\&W's contribution to the Task 6 final topical report will continue.

- Fabrication of Demonstration Article "B" (thick wall header assembly) will be completed.

TABLE 6

Schedule and Progress

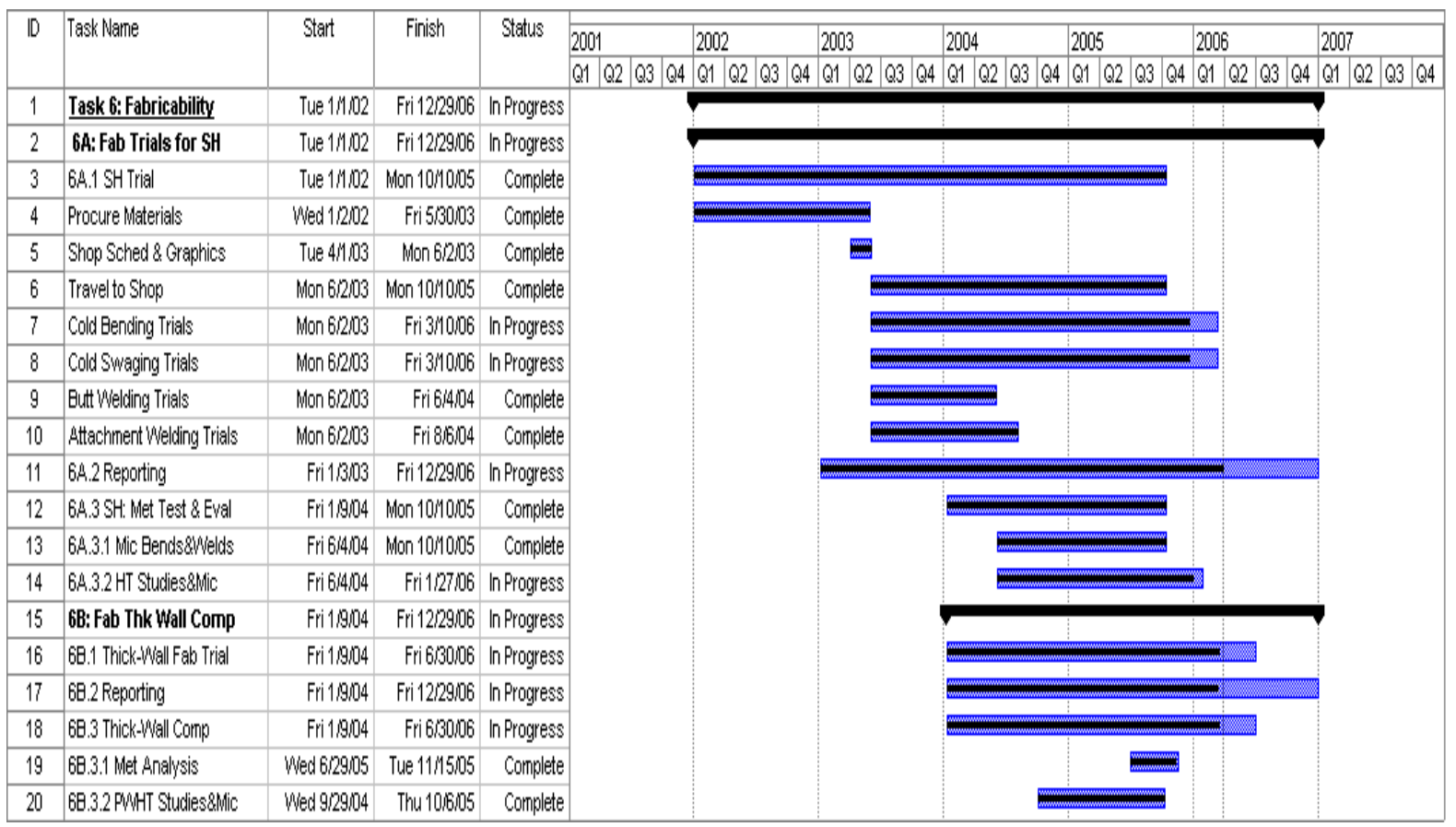




\section{Task 7 \\ Coatings \\ (Alstom)}

Objectives for Task 7 Coatings:

- Review state-of-the-art of coating technology and identify development needs.

- Develop coating manufacturing techniques, which can provide corrosion/erosion protection for components in USC boilers, cost effectively.

- Establish manufacturing techniques for application of internal coatings for oxidation protection, cost effectively.

- Provide coated samples for corrosion and oxidation testing in the laboratory and "in the field".

These objectives will be accomplished through execution of eight sub-tasks. Where activity on these sub-tasks occurred during the reporting period, it is described below.

\section{Task 7G: Manufacturing Guidelines}

\section{Objective:}

Investigate the requirements for production coating of boiler materials.

\section{Progress for the Quarter:}

Work efforts for this task have concentrated on the requirements for diffusion-coating of the internal surface of boiler tubing. Editing of the task report was deferred to next quarter.

\section{Concerns:}

No concerns at this time.

\section{Plans for Next Quarter:}

Issue a report of the manufacturing requirements and costs for coating of internal tube surfaces. 


\section{Task 8 \\ Design Methods and Data \\ (Alstom)}

The major objectives for Task 8 are:

- Review the methods used by Section I of the ASME Boiler and Pressure Vessel Code to utilize materials properties and behavior models in the design of ultrasupercritical boilers.

- Develop and document methodologies whereby the results of the other tasks within this program may be most effectively applied within the ASME Section I design environment.

- Pursue the incorporation of such methodologies into Section I.

These objectives will be accomplished through execution of seven sub-tasks. Where activity on these sub-tasks occurred during the reporting period, it is described below.

\section{Task 8A: Task Management (ALSTOM)}

\section{Objective:}

The primary objective of this subtask is the overall management of the task, coordinating meetings and preparing progress reports.

\section{Progress for the Quarter:}

Progress continued to be rather slow although some tangible progress was made on the weld literature review. Limited material data availability and resource issues continue to hamper progress on some tasks.

\section{Concerns:}

No concerns at this time.

Plans for the Next Quarter:

Continue general task management activities. 


\section{Task 8B: Material Data Collation and Processing (FW)}

\section{Objective:}

The creation of documentation to ensure that quality test data is transferred between tasks and that this data remains traceable. A second objective is the analysis of such data with the objective of improving the statistical correlation. Foster Wheeler is subtask leader, with Riley Power Inc. providing significant input to this subtask.

\section{Deliverables:}

\begin{tabular}{|l|l|l|}
\hline \multicolumn{1}{|c|}{ Item } & Responsible & \multicolumn{1}{c|}{ Status } \\
\hline Material data transfer sheets & ALSTOM & $\begin{array}{l}\text { Transfer sheets provided for } \\
\text { creep and tensile tests. }\end{array}$ \\
\hline Electronic data repository & ORNL & Website complete. \\
\hline Recommendations for statistical analysis of data & & \\
\hline Data compendia and fits for key materials & & \\
\hline $\begin{array}{l}\text { Code case packages and submissions to code } \\
\text { committees }\end{array}$ & ALL & \\
\hline
\end{tabular}

\section{Progress for the Quarter:}

Riley Power Inc. has continued to monitor the USC data transfer website for any added completed test results for the HR6W and SAVE 12 materials, assigned to Riley. Recent new postings to the USC data transfer website include, the creep rupture results for Test No. 30677, Specification No. 617W-03, an HR6W weldment with Alloy 617 welds. This completes the scheduled creep rupture test results for the HR6W material. Currently for HR6W, the only missing results are for metallography. In addition, the creep rupture parameters for in-process Test No. 30682, Specification No. SVE12-01, a SAVE 12 pipe specimen, have been posted.

ALSTOM Power Inc. met with ORNL to review mechanical feature testing, specifically the thermal shock testing of CCA617. ORNL provided some preliminary test results, including thermocouple traces, from which ALSTOM completed a simple structural analysis of the hollow cylindrical specimen, which is heated externally and cooled on the inside bore. These results indicated that the cracking could be a result of cyclic creep, which raised a number of questions about the yield strength of CCA617. ORNL took actions to explore the tensile behavior of CCA617 and to perform more frequent inspection for cracks in future tests.

\section{Concerns:}

No concerns at this time. 


\section{Plans for the Next Quarter:}

The task participants will continue to monitor the USC data transfer web site for any additional, completed test results. Evaluations will continue to compare and contrast the strength of the materials with existing databases for similar alloys. Riley will complete the in process summary report of the test results for the HR6W material. It is projected that it will not be possible to work on statistical correlation of data for some time because of the lack of data on which to perform meaningful analysis. Support will be provided to Task 2, as needed, to address issues with additional structural feature tests, or interpretation of existing tests.

\section{Task 8E: Continuum Damage Mechanics (B\&W)}

\section{Objectives:}

The objective of this subtask is to analyze uniaxial and multiaxial creep test data from Task 2 for several (three) materials to:

- establish the continuum damage mechanics (CDM) parameters,

- evaluate multi-axial strength theories and failure criteria,

- assess the implications of cyclic creep for USC materials,

- evaluate and compare CDM, reference stress and Omega models of typical ASME geometries.

\section{Progress for the Quarter:}

The continued scarcity of long-term creep data for the candidate materials means that the effort to model the creep response with continuum damage mechanics or other models remains on hold. Furthermore limited multiaxial creep rupture data are available (one notch bar test for IN740) so determination of the multiaxial stress rupture criterion cannot proceed.

The study to assess the cycling capability and margins against shakedown and ratcheting for a typical segment from a superheater header, which was completed last quarter, was formatted into a topical report and awaits final internal review by ALSTOM prior to a draft being sent to other project participants.

\section{Concerns:}

Timely availability of creep data on ORNL web site and results of notched bar creep rupture tests. 


\section{Plans for the Next Quarter:}

Monitor material data web site to see if sufficient data is available to initiate a modeling activity. Check on status of structural feature tests. Issue topical report on the study comparing cycling capability of candidate alloys.

\section{Task 8F: Weld Analysis and Assessment (ALSTOM)}

\section{Objective:}

Create simplified analysis models of welds and heat affected zones (HAZ) utilizing material properties obtained from the open literature and from Task 2 to permit accurate creep life assessment of weldments.

\section{Deliverables:}

\begin{tabular}{|l|l|l|}
\hline \multicolumn{1}{|c|}{ Item } & Responsible & \multicolumn{1}{c|}{ Status } \\
\hline $\begin{array}{l}\text { Topical review of weld analysis and assessment } \\
\text { in creep range. }\end{array}$ & ALSTOM \& RPI & In progress. \\
\hline Collation of material data for weld metal and HAZ. & RPI & In progress. \\
\hline Creep models for weld metal and HAZ regions. & ALSTOM & In progress. \\
\hline $\begin{array}{l}\text { Report documenting the simulation of welded } \\
\text { specimens and common Code geometries. }\end{array}$ & ALSTOM & \\
\hline $\begin{array}{l}\text { Report documenting the development and use of } \\
\text { approximate weld assessment methods. }\end{array}$ & ALL & \\
\hline
\end{tabular}

\section{Progress for the Quarter:}

Riley Power Inc. has previously submitted their contribution to the weld literature review and awaits ALSTOM's contribution so that a complete document can be reviewed, edited as necessary and issued to the project team.

ALSTOM continued studies of high-temperature design approaches for weldments. The attractive features of the reference stress method that were previously identified were explored further in a series of analyses that compared the results of full creep continuum damage mechanics calculations (for so-called model materials) against the approximate reference stress method. This approach permits a range of scenarios such as weak weld metals, indicative of nickel-based alloy weldments, and weak heat affected zones, indicative of ferritic steel weldments, to be explored for a range of geometries and loads that would not be possible in a laboratory test program. The results of the study show that the reference stress method is capable of predicting key trends and provides reasonable estimates of the strength of a variety of weldments. The results have been written up in a draft report, which has been combined with 
previous contributions from Riley Power. This report in presently under internal review within ALSTOM Power and will be issued as a draft to other task participants early in the next quarter.

\section{Concerns:}

No concerns at this time.

\section{Plans for the Next Quarter}

In the next quarter, ALSTOM will complete their portion of the weld literature review and work with Riley Power to issue the weld literature review summary report. Also, the weld creep rupture test data for nickel-based alloys will be compared and contrasted to help guide future modeling efforts.

\section{Task 8G: Basic Design Rules for Cylinders (ALSTOM)}

\section{Objectives:}

Review the various equations used by the ASME Code, Section I for Power Boilers to define the minimum thickness of cylinders under internal pressure and develop a single methodology applicable to ultrasupercritical boilers.

Deliverables:

\begin{tabular}{|l|l|l|}
\hline \multicolumn{1}{|c|}{ Item } & Responsible & \multicolumn{1}{c|}{ Status } \\
\hline $\begin{array}{l}\text { Report summarizing existing approaches and } \\
\text { comparing and contrasting their predictions }\end{array}$ & ALSTOM & Complete (Aug 2003) \\
\hline $\begin{array}{l}\text { Report recommending a single equation with } \\
\text { supporting theoretical data. }\end{array}$ & ALSTOM & Complete (Sept 2003) \\
\hline Code case submission & ALSTOM & Complete (October 2003) \\
\hline
\end{tabular}

\section{Progress for the Quarter:}

No activity for this quarter.

\section{Concerns:}

No concerns at this time.

\section{Plans for the Next Quarter:}

No plans at this time. 


\section{Task 9 \\ Project Integration and Management (EPRI)}

- The objective of Task 9 is to coordinate the project and provide reporting to DOE and Ohio Coal Development Office (OCDO).

Progress for the Quarter:

- Completed first Quarterly Report for 2006.

- Completed Monthly Reports for January and February, 2006.

- Monthly conference calls were held and the discussions were documented.

Concerns:

- No concerns at this time.

Plans for the Next Quarter:

- Issue monthly reports and hold conference calls as required.

- Conduct Steering Committee Meeting in Cleveland on May 3rd and 4th, 2006 and provide minutes. 